Original Article

Received/Accepted Dates

05.11.2021/21.12.2021

DOI: 10.52096/jsrbs.7.14.3
Journal of Social Research and Behavioral Sciences

Sosyal Araştırmalar ve Davranış Bilimleri Dergisi

ISSN:2149-178X

Volume: 7 Issue: 14 Year: 2021

\title{
An Examination of Fantasy Illustration and the Illustrations of Pauline Baynes and John Howe Through the Writings of J. R. R. Tolkien
}

\author{
Res. Asst. Dr. Baris HASIRCI \\ Mersin University \\ barishasirci@gmail.com \\ ORCID: 0000-0001-9117-4476
}

\begin{abstract}
J. R. R. Tolkien, known for originating "The Lord of the Rings" trilogy is one of the most acclaimed authors of fantasy literature whose work has captured the imagination of people of all ages and backgrounds. It is evident that through his work, Tolkien is able to kindle in the hearts of his readers desire for a new world and adventures. In the article, the aim is to focus on Tolkien's ideas on fantasy illustration as relayed in his essays and letters to understand how illustrators may enliven feelings of wonder as Tolkien has done with his words. The style he has employed to create his own illustrations, his criteria for selecting illustrations to be published with his works, why he was partial to the illustrations of Pauline Baynes and the similar qualities found in the works of John Howe, who is one of the most widely recognized illustrators of Tolkien's work is discussed. Through this study, the essence of the works of Tolkien that have such a strong impact on readers and the qualities that fantasy illustrations of today should possess in the pursuit of creating a desirable "Secondary World" for the readers' imaginations to enter may be discovered.
\end{abstract}

Keywords: Fantasy illustration, Secondary World, desire, Arts \& Crafts Movement, the Golden Age of British Illustration

\section{Özet}

Eserleriyle her yaştan ve hayat koşulundan insanın hayalgücünü süslemiş olan, "Yüzüklerin Efendisi" üçlemesinin yazarı J. R. R. Tolkien fantastik edebiyatın en önemli yazarlarındandır. Tolkien, eserleri yoluyla okurlarının gönlünde yeni bir dünyaya ve serüvene duyulan arzunun kıvılcımını parlatmayı başarır. Resimlemecilerin, çalışmalarıyla Tolkien'in okurlarında uyandırdığı duyguları nasıl uyandırabileceklerinin anlaşılması için yazarın makaleleri ve mektuplarında yer alan fantastik resimlemeyle ilgili görüşlerinin 
irdelenmesi makalenin odağındadır. Kendi hazırlamış olduğu resimlemeler, kitaplarında kullanılacak resimlemelerin seçilmesinde önemsediği ölçütler, Pauline Baynes'ın resimlemelerine duyduğu derin ilgi ve Tolkien kitaplarının ünlü resimlemecilerinden John Howe'ın çalışmalarının Baynes’ın çalışmalarıyla ortak olan özellikleri incelenmektedir. Bu yöntemle, Tolkien'in yazılarının toplulukları etkileyen ve bugünün fantastik resimlemelerinin hayranlık uyandırıcı "İkincil Dünya"lar yaratmak için sahip olması gereken özellikler ortaya çıkarılmaya çalışılmıştır.

Anahtar Sözcükler: Fantastik resimleme, İkincil Dünya, arzu, Arts \& Crafts Akımı, Britanya Resimlemesinin Altın Çağ

\section{Introduction}

John Ronald Reuel Tolkien, the English philologist and academic best known as the author of "The Lord of the Rings" trilogy of books may be cited as the originator of modern fantasy literature due to the love and adoration his work has been received with by the book reading public ever since the works have first seen print. Professor Tolkien's work has reached readers from all walks of life, from children to adults which might be credited to it having the ability to excite readers and create in them the desire for the imaginary lands and adventures that he has created to be real. The pictures Tolkien creates with his words are richly detailed and vividly colored enough on their own to create a fascinatingly believable world in the minds of the readers and still, many readers, when reading the books may be met with the illustrations provided for the covers of the books, the posters, the maps and such products created for the promotion of the work by many talented artists, when they look with their mind's eye at the text. The first illustrator to have created such work is none other than Professor Tolkien himself who provided the dustjacket and the inside illustrations for the first printing of The Hobbit, the first book detailing the happenings of the imaginary world of "Middle-Earth". The author has also illustrated some lesser-known works of his and the illustration duties of the Middle-Earth books has relied on professional illustrators since The Hobbit's first printing.

With this article, the aim is to focus on Tolkien's ideas on fantasy illustration as relayed in his essays and letters to understand how illustrators may enliven feelings of wonder as Tolkien has done with his words. The style he has employed to create his own illustrations, his criteria for 
selecting illustrations to be published with his works, why he was partial to the illustrations of Pauline Baynes and the similar qualities found in the works of John Howe, who is one of the most widely recognized illustrators of Tolkien's work is discussed. Through this study, the essence of the works of Tolkien that have such a strong impact on readers and the qualities that fantasy illustrations of today should possess in the pursuit of creating a desirable new world for the readers' imaginations to enter may be discovered.

\section{Tolkien on Fantasy and Illustration}

J. R. R. Tolkien believes that the making of fantasy is a natural human activity for humans are makers, created in the image of a Maker and thus have the willingness to make out of thin air (Tolkien, 2008: 225). The idea that it is intrinsic in people to create is manifested in Tolkien's writing in many places such as in the "Vala", deities serving under the ultimate creator Eru Iluvatar, that may be considered to be sub-creators; especially Aule, who creates and cares for the dwarves in secret from Eru Iluvatar, in the work by Professor Tolkien titled "Silmarillion". The elves in the story also display a love for making through their many types of craft, using the world's resources to fashion them into beautiful objects such as the three immaculate jewels named "Silmaril"s.

Professor Tolkien regards the creation of fantasy as the creation of a "Secondary World" that, when done well the reader's mind can enter, leaving the "Primary World" behind. For this to be achieved, the sub-creator of literature must be able to produce "literary belief" thus, inside the Secondary World, what is related is true according to the laws of that world (Tolkien, 2008: 215). This type of belief is different from the actual need to believe. Professor Tolkien makes the distinction that the enjoyment of a story is not dependent on the belief that what has been relayed has or can take place in the real world. For him, what is essential is the "desirability" of the Secondary World; a desire for such places, characters, adventures to exist. The sub-creator of the Secondary World of the fairy-story succeeds once desire in the reader is awakened, satisfied and also fueled (Tolkien, 2008: 217).

Desire for a Secondary World created in a reader through fairy-stories has four components according to Professor Tolkien: "Fantasy", "recovery", "escape" and "consolation" (Tolkien, 
2008: 220). He notes that the human mind is capable of forming mental images of things that are free from the observed facts of the Primary World. Fantasy is close in essence to elvish "enchantment" by making use of this ability to imagine the fantastic; it is made out of the feeling of the Primary World, to create desire for life through a shared delight in making. "Recovery" as the renewal of health, is like the cleaning of the minds windows which gives allows the individual to see the overlooked with fresh attention. "Escape" is described as going as free as a bird to a Secondary World that is lovelier than the Primary World the individual finds themselves in. It is also stated by the professor that all great works of literature are mainly about death (Izzard, 1968), therefore another aspect of escape is described as the one from death. This point is presented in his work as characters who are immortal, mortal characters achieving everlasting life or characters like Frodo in the Lord of The Rings who go beyond the borders of the mortal world to reach the undying lands. Lastly, yet perhaps more importantly, comes the quality that all fairy-stories must possess which is "consolation", as in "the consolation of the happy ending". Professor Tolkien notes that there is no true end to fairy-stories but there is a sudden miraculous turn of "joy beyond the walls of the world" in the afterlife (Tolkien, 2008: 221-233). These four qualities together create in the receiver of the fairy-story the desire for this type of Secondary World. It might be deduced that the illustrations accompanying the fairy-story should display these qualities to a certain extent.

Fantasy, recovery, escape and consolation are the main qualities that Professor Tolkien points out that fantasy literature must possess and before going into his ideas on the qualities that fantasy illustration should display, it is important to note that Professor Tolkien believes that fantasy is an art form best served by literature for the visual representation of a subject tends to "outrun the mind" and overthrow it (Tolkien, 2008: 222). All art that offers visual representation imposes one form on a subject whereas literature works from mind to mind which makes it more universal and particular at the same time (Tolkien, 2008: 239). When an object, a living thing or a place is described in literature, the "ideal" form of that thing is invoked as Plato puts it (Plato, 2004: 198), which encompasses the particular form each reader gives it in their imagination according to their specific make up. Where an illustrator succeeds in presenting a particular landscape with a hill, river and valley, literature provides hill-ness, river-ness and valley-ness which are open to interpretation and take shape in the readers' mind. Therefore, Professor Tolkien suggests that it is easier for the mind to enter such a Secondary World. While his belief is as such, he himself is the 
first illustrator to work on his books; in 1937, the first edition of The Hobbit was published with nine of Professor Tolkien's ink drawings with an additional frontispiece and a color dustjacket.

In a passage about the importance of "recovery" found in fantasy, Professor Tolkien states that one may get too familiar with drawing that exudes skill and seek out new qualities that are "wilfully awkward" (Tolkien, 2008: 227). He believes that originality should be found in the finer qualities of the arts:

- We do not, or need not, despair of drawing because all lines must be either curved or straight, nor of painting because there are only three "primary" colours. We may indeed be older now, in so far as we are heirs in enjoyment or in practice of many generations of ancestors in the arts. In this inheritance of wealth there may be a danger of boredom or of anxiety to be original, and that may lead to a distaste for fine drawing, delicate pattern, and "pretty" colours, or else to mere manipulation and over-elaboration of old material, clever and heartless. But the true road of escape from such weariness is not to be found in the wilfully awkward, clumsy, or misshapen, not in making all things dark or unremittingly violent; nor in the mixing of colours on through subtlety to drabness, and the fantastical complication of shapes to the point of silliness and on towards delirium. Before we reach such states we need recovery... This recovery fairy-stories help us to make. In that sense only a taste for them may make us, or keep us, childish. (Tolkien, 2008: 227).

While Professor Tolkien uses this comparison as an example to show that fairy-stories help keep the perspective of readers fresh like a child's, his description seems to indicate that in his preference of illustration he tends to prefer qualities that are aimed at beautifying such as "fine drawing" and "delicate pattern".

The importance of patterns and ornamentation for Professor Tolkien is evidenced in his writing where he discusses that borders should accompany illustrations: "It was an irresistible development of modern illustration (so largely photographic) that borders should be abandoned and the 'picture' end only with the paper. This method may be suitable for photographs; but it is altogether inappropriate for the pictures that illustrate or are inspired by fairy-stories" (Tolkien, 2008: 241). It is the professor's belief that the illustration of a fantastical place needs a margin or an elaborate border, as evidenced in his illustrations (Fig. 1). The presentation of an illustration as a photograph of a certain landscape is not his preferred approach, thus he seems to prefer 
illustrations that, rather than belief, create desire. The idea of the border seems to support this idea since it is another element that points to the fact that the illustration is not of an actual place, event or individual but rather an idealized representation. This quality allows the viewer's imagination to use the illustration as a jumping off point to better visualize the Secondary World in their mind's eye.

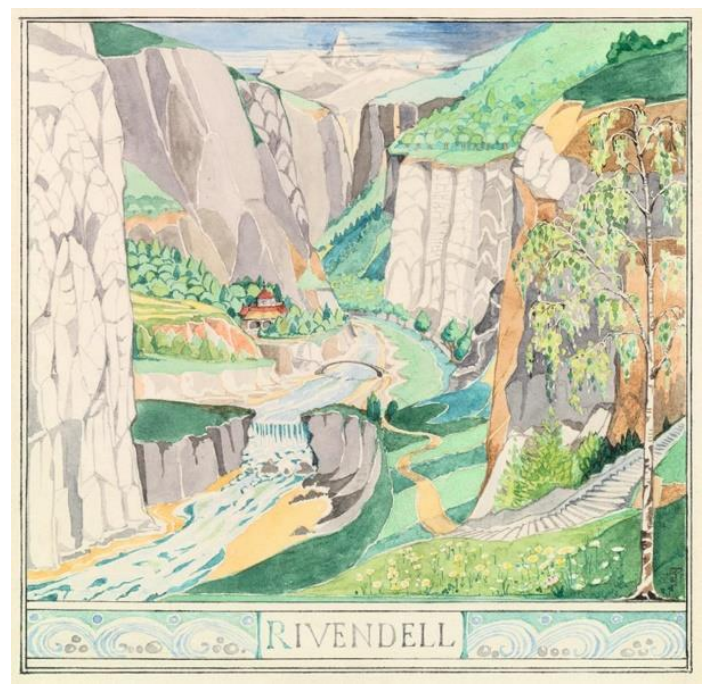

Figure 1. Tolkien, J. R. R. (1937). Rivendell, from The Hobbit. George Allen \& Unwin Ltd.

In the previous paragraphs, "desire" as the fundamental quality of fantastic literature that is kindled in the hearts of readers through evocation of the notions of fantasy, recovery, escape and consolation has been discussed. For this feeling to be achieved, Professor Tolkien states that belief in places, things and adventures that take place in fantasy is not necessary and a similar approach must be employed in the creation of illustrations. This requires that illustrations look not like photographs of an actual place but rather conjure an idealized image. This image should be presented with the clear notion that it is an illustration that is to be used in the beautification of a book that is almost an artifact itself. As in illuminated manuscripts of old, it would be befitting that these illustrations be contained within the margins of elaborate borders. These traits point towards the tendency of Professor Tolkien to favor elements such as fine drawing, delicate pattern, subtle mixing of colors and fantastical complication of shapes in the creation of illustrations. The aspects described are evidenced in his own illustrations and an analysis of some of his works and the common traits found among them may lead to a better understanding of the way the professor deemed to create desire through his artworks. 


\section{Tolkien's Influences in Illustration}

J. R. R. Tolkien seems to have displayed a fondness for drawing since his early years for there are drawings of his' from those formative years. It is reported that he takes his first art lessons from his mother who was a capable artist, being from a family of engravers and plate makers (Hammond, Scull, 1995: 12). Although Professor Tolkien produces pictorial art throughout his life, he is not satisfied with his level of skill as may be observed in a letter to Susan Dagnall of the publishing house George Allen \& Unwin Ltd. concerning the illustrations he was preparing for The Hobbit: "I can only hope - as I have small skill, and no experience of preparing such things for reproduction - that they may possibly serve" (Carpenter, Tolkien, 2000: 20). It is with these thoughts Professor Tolkien sends his illustrations to the publishing house and later is surprised to find that the “indifferent pictures" he has provided for The Hobbit are accepted (Carpenter, Tolkien, 2000: 2122). Having a deep love of nature as evidenced in his writing, his pictorial art mostly consists of depictions of nature. In response to a letter by Rayner Unwin in which Mr. Unwin asks if the professor could suggest a suitable drawing of a tree for the cover of his book "Tree and Leaf", Professor Tolkien writes that there is more than one version of a mythical tree he comes up with time and again when he feels driven to do pattern designing (Carpenter, Tolkien, 2000: 360). From these words, his love of trees and of pattern designing may be observed.

Having been born in 1892 in South Africa, then moving to England three years later, it may be presumed that Professor Tolkien must have been aware of the decorative arts that had flourished in his youth, namely that of the Arts and Crafts movement inspired by the ideas of British artist and author William Morris. Morris's book "Some Hints on Pattern Designing” is said to have been owned by Professor Tolkien (MacLeod, Smol, 2017: 115) and that this sense of delicate decoration maybe be observed in the borders on some of his illustrations and the elaborate symbols he painted in relation to The Silmarillion.

William Morris who is possibly one of the bigger influences on Professor Tolkien's literary and pictorial output, is a textile designer associated with the Arts and Crafts movement and a social activist, poet and novelist. His literary work may be credited as being instrumental in the establishing of the modern fantasy genre through his influence on Professor Tolkien. It is reported that Morris created over 600 textile, embroidery and wallpaper designs, over 150 designs for 
stained glass windows, produced the Golden, Troy and Chaucer typefaces designed in the vein of early printers' works and worked on up to 650 ornamentations for Kelmscott Press, the publishing house he founded to produce limited edition books which were prepared in the manner of illuminated manuscripts (Fig. 2) (Clutton-Brock, 2007: 110).

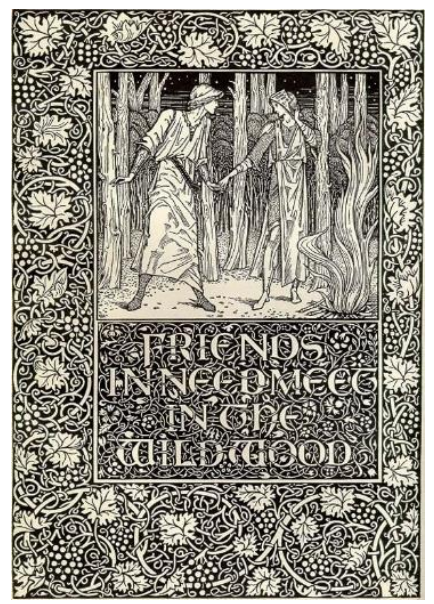

Figure 2. Burne-Jones, E. (1896). Friends in Need Meet in the Wildwood, from The Well at the World's End. Kelmscott Press.

When he is a student at the Oxford University, William Morris grows to admire Medievalism and the Medievalist paintings of the Pre-Raphaelites that display chivalric values. The group of English painters, poets and art critics including Edward Burne-Jones and Dante Gabriel Rossetti called the Pre-Raphaelites whose style is heavily inspired by Medievalist art motivates Morris to form close friendships with them. He associates with the views of art critic John Ruskin, rejecting the industrial manufacture of uninviting products due to unhappy working conditions, favoring a return to craftsmanship. This point of view also puts forth the purpose of art as being the painting of mainly Christian events and the imitation of nature as is the case of works from before the time of Raphael. What this means is that art should be richly detailed, vividly colored and built upon complex compositions (Sizeranne, 2008: 175-176).

William Morris founds Kelmscott Press in 1891 with the ideals of John Ruskin and the influence of the Pre-Raphaelites to produce books using traditional printing methods. Employing these methods and materials, his ambition is to produce "a perfect work to restore all the beauty of illuminated lettering, richness of gilding and grace of binding that used to make a volume the treasure of a king" (Bradley, 1896: 9). Since 19th and 20 th Century art movements showcase an interest in typographical design, Morris uses medieval motifs and typography to enrich the design 
of the books of the publishing house. He designs three typefaces presented with intricate floral borders as in illuminated manuscripts. The love and usage of borders and frames with floral patterns may remind the reader of Professor Tolkien's preference of illustrations having borders. Apart from being a prolific designer, William Morris is also a renowned writer of poems, essays and novels. He translates sagas such as The Saga of Gunnlaug Worm-Tongue, a name which may bring to mind the Tolkien character "Grima Wormtongue". In his later years, Morris pens some works that may be classified as fantasy fiction since the events described take place entirely in fantasy worlds such as The Wood Beyond the World and The Well at the World's End, with characters such as “Gandolf” whose name is very similar to Tolkien's famous wizard "Gandalf”. These works have their influence on many later fantasy writers such as Professor Tolkien himself, who notes that he is unable to produce better work than Morris' (Scull, Hammond, 2017: 816).

It is believed that along with the impact of William Morris' works on him, Professor Tolkien was also influenced by the illustrated books of his youth at the beginning of the $20^{\text {th }}$ Century that contained artwork by British illustrators like Warwick Goble, Arthur Rackham, Charles Robinson, Edmund Dulac and Jennie Harbour who are considered as having taken part in "The Golden Age of British Illustration" (Hammond, Scull, 1995: 10). This period also sees the rise in popularity of works by non-British illustrators such as Jessie Willcox Smith, Kay Nielsen and Maxfield Parrish. It may be stated that the illustrated works produced from the early 1800 s to early $20^{\text {th }}$ Century, in what is considered to be The Golden Age of British Illustration is brought about by the fact that newspapers, magazines, and illustrated books became the main media in Europe and America where the reproduction of art made possible by new technology allows for experimentation with rendering techniques and leads to an unprecedented quality in illustration. The illustrators of this period are also influenced by the Pre-Raphaelites (Leroy, 2016: 175) together with the art movements like the aforementioned Arts and Crafts and Art Nouveau. The Golden Age of British Illustration is said to have lasted until the beginning of the First World War in 1914, when the public's taste for high quality books containing fairy stories starts to decline.

One illustrator that must have had an influence on Professor Tolkien with the distinctive character he illustrates trees with is Arthur Rackham (Fig. 3), who makes his first forays into the world of professional illustration with works included in the Pall Mall Budget weekly magazine (Menges, 2008: 10). He comes into prominence with his illustrated books in the 1980s, when he commits to 
a being a full-time illustrator.
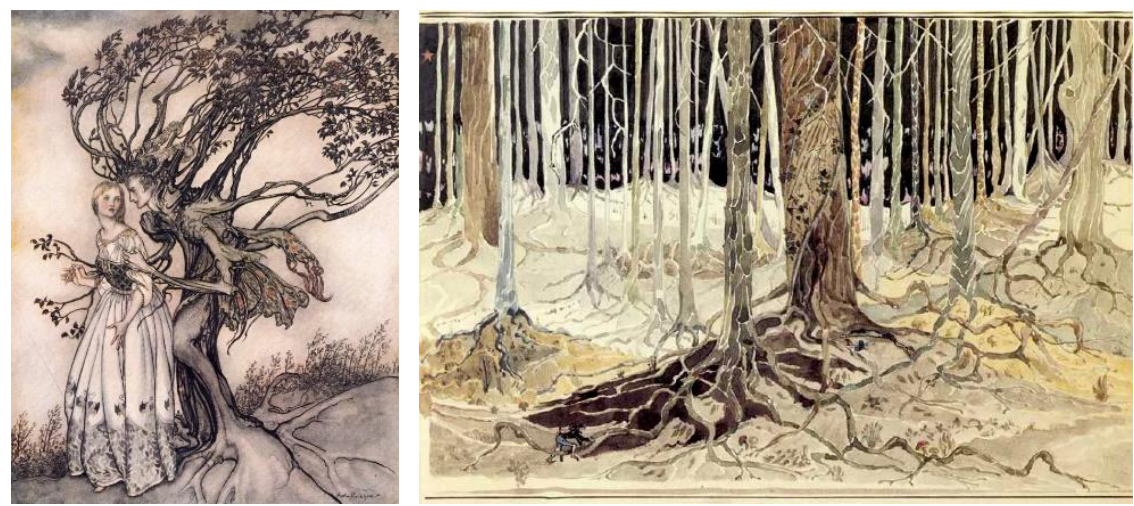

Figure 3. (Left) Rackham, A. (1917). Suddenly the BranchesTwined Round Her and Turned Into Two Arms, from The Old Woman in the Wood. Constable \& Co. Ltd. / (Right) Tolkien, J. R. R. (1937). Fangorn Forest, from The Hobbit. George Allen \& Unwin Ltd.

It is noted that the artist works mainly with pen and ink, in a technique that carries with it a unique, personal and soulful line quality which he developed while working on journalistic illustrations, sometimes combined with watercolor. While he used lines made with a soft pencil to plan out his pen and ink illustrations and later removed them, for his color work where he employed watercolor, he opted to build from multiple washes of translucent tints. In the early days of 3-color printing, the definition of lines could be lost therefore the illustrator would resort to going over his lines, inking them again after the process with the watercolors. He would also make use of silhouette cutouts. Rackham's style has been described as a mixture of northern European style and the early 19th century Meiji era Japanese woodblocks (Peitcheva. 2016: 4). J. R. R. Tolkien's illustration work also displays some of these traits.

While it may be mostly speculated that the works of Arthur Rackham and Kay Nielsen may have had an influence on Professor Tolkien, it is clearly observable the effect the art of Jennie Harbour has had on his illustrations. Little is known of Ms. Harbour who is believed to have been born in 1893 in London. In 1919, at the age of 26, it is recorded that she starts working for The Raphael Tuck Publishing Company, illustrating postcards and calendars which are described as being “delightfully distinctive, bright and pleasant" (Phillips, 1919: 18). Between 1921 and 1934, she illustrates many books of fairy tales including "My Favourite Book of Fairy Tales", "The Yellow Fairy Book" and "The Green Fairy Book" which present on its pages, stories such as "The Fisherman and His Wife" and "The Story of the Three Bears". During this time, her illustrations 
seem to capture the public's imagination with graceful outlines and original color palettes, having subtle washes of color, few, black outlines and energetic patterns (Pook Press, 2018).

It is noted that the Tolkien household of the professor's youth had harbored many illustrated books and that even though many of these books were later lost, he made up for it by the libraries he created for his sons and daughter (Hammond, Scull, 1995: 10). The basic composition of an illustration made for The Hobbit depicting the trolls in the forest by Professor Tolkien seems to be closely influenced by Harbour's illustration of Hansel and Gretel produced for "My Book of Favorite Fairy Tales" first printed in 1920 (Fig. 4), a book that was supposedly owned by Professor Tolkien (Hammond, Scull, 1995: 109). The elaborate dotted pattern visible on the trees and around the campfire, the lines of the flames and the smoke reminiscent of Art Nouveau, the contrast of the black and white in both illustrations seem to indicate that Professor Tolkien found this type of illustration effective in conveying the fantastical nature of his story.
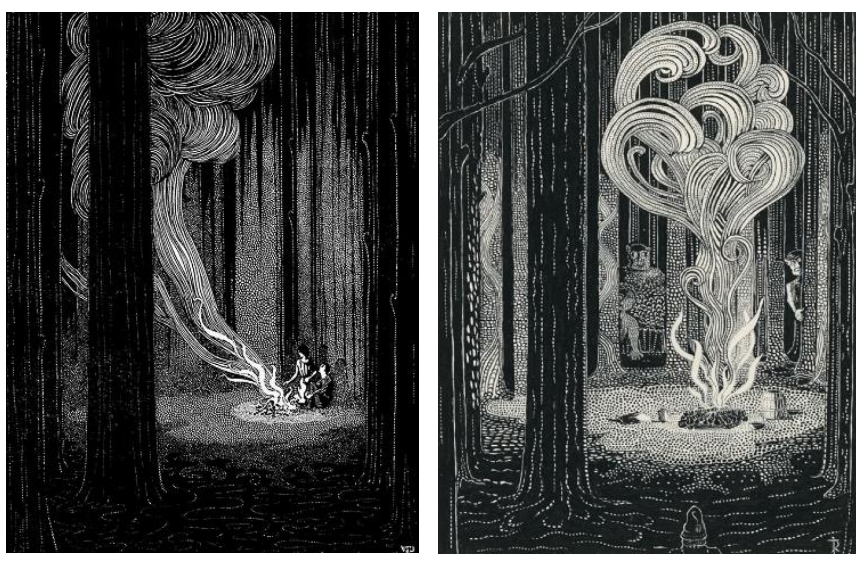

Figure 4. (Left) Harbour, J. (1921). Hansel and Grethel Sat Down by the Fire, from My Book of Favourite Fairy Tales. Raphael Tuck \& Sons. / (Right) Tolkien, J. R. R. (1937). The Trolls, from The Hobbit. George Allen \& Unwin Ltd.

In a letter to a fan of The Lord of the Rings, Professor Tolkien describes an incident where a man asks whether the professor's imagination has been fed on pictures that seem to him to illustrate the books from before their publication. The professor responds by stating that even though his imagination is fed by literature and languages, he is not well acquainted with pictorial art (Carpenter, Tolkien, 2000: 450). While this statement may be true for the creation of his literary Secondary World, perhaps there is a possibility that he may have taken notice of the kinds of illustration that came close to capturing the feeling he was trying to kindle in the hearts of his 
readers and Jennie Harbour's is one such style of illustration.

In this chapter, the influences from Professor Tolkien's childhood that have helped shape his creative output, namely the works of William Morris who is inspired by the Pre-Raphaelites and also the artists of The Golden Age of British Illustration such as Arthur Rackham, Kay Nielsen and Jennie Harbour who are influenced by the Arts and Crafts movement of William Morris have been discussed. The artistic approaches of these artists and art movements are visible in Professor Tolkien's writing as well as his pictorial work. How their methods of creating desire in a Secondary World have found a place in the professor's artwork will be examined further in the upcoming chapter.

\section{Tolkien's Own Illustrations}

J. R. R. Tolkien wished to kindle the feeling of desire for a fantastical world rather than create belief in it with his literary work, yet there are clues that he wanted his Secondary World to come as close to the Primary World as much as possible almost to the point of having the two interact. The dwarvish runes on the borders of the dustjacket of the first printing of The Hobbit (Fig. 5) state that the book, rather than having been written was compiled by the professor from the memoirs of one Bilbo Baggins, a Hobbit. The idea of having authentic artifacts, facsimile copies of maps, calligraphic writing, runes and tile designs from a Secondary World is seen time and again in the professor's work; from the map of Middle-Earth included in the Lord of the Rings books, the elvish calligraphy and dwarvish runes presented within the text of The Hobbit, to the floral patterns designed and illustrated to represent the many houses of elves and men in the Silmarillion.

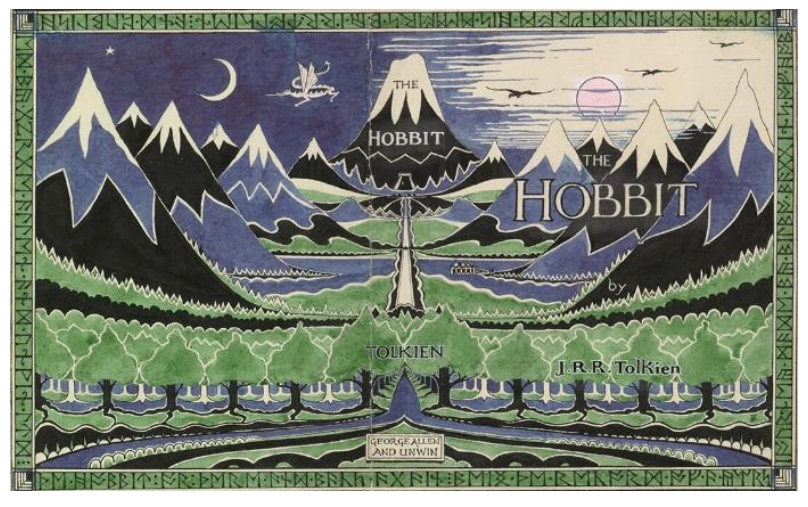


Figure 5: Tolkien, J. R. R. (1937). The dustjacket illustration and design for The Hobbit. George Allen \& Unwin Ltd.

While artwork such as calligraphy, runes, facsimile copies of maps were made to seem as actual artifacts coming to the Primary World from the Secondary World, the professor also made illustrations that represented places, peoples, things and events that were presented in his stories. One such illustration is the aforementioned dustjacket for The Hobbit Professor Tolkien designed and illustrated. Sending the dustjacket to publishers Allen \& Unwin for critique, the professor notes that the effort is beyond his craft yet thinks that perhaps the design is somewhat suitable. He goes on to evaluate his work:

- There are too many colours: blue, green, red, black... The presence of the sun and moon in the sky together refers to the magic attaching to the door. It is too complicated, and needs simplifying: e.g. by reducing the mountains to a single colour, and simplification of the jagged 'fir-trees'... In redrawing the whole thing could be reduced - if you think the runes are attractive. Though magical in appearance they merely run: The Hobbit or There and Back Again, being the record of a year's journey made by Bilbo Baggins; compiled from his memoirs by J. R. R. Tolkien and published by George Allen \& Unwin (Carpenter, Tolkien, 2000: 23).

Along with the dustjacket, the professor submits one frontispiece and 9 other illustrations in black and white and also makes illustrations that do not find a place in the book. The ornamentally framed illustrations generally focus on landscapes, places, architecture and nature, giving little to no space for the characters and creatures. While light and atmosphere are made to appear realistic and convey actual natural weather and lighting conditions, the elements of nature such as trees, mountains and valleys are highly stylized, with flat areas of color separated by lined borders. These illustrations are not made to look like snapshots of an actual place but draw attention to the fact that they are illustrations prepared to decorate a book. This is the approach Professor Tolkien chooses to illustrate his books whereas there is artwork of his that clearly showcase that he is capable of making illustrations with a more realistic quality. It is as if the professor does not want to interfere with the readers' experience of the images created in their heads from the words and rather wants to give a slight hint, a vague direction for the imagination to use as a guide post.

The views of Professor Tolkien on the work of some of the illustrators that have illustrated or 
submitted work to be considered to be used in his books, shed more light on his criteria for selection of artwork to be displayed alongside his text and perhaps his thoughts on what makes good fantasy illustration.

There have been many illustrators that have illustrated books by Professor Tolkien, one being Ms. Mary Fairburn who had sent the professor work in early May of 1968 to be considered to be included in one of the editions of The Lord of the Rings books (Scull, Hammond, 2017: 1049). In a subsequent letter, Professor Tolkien writes to Ms. Fairburn remarking that he finds the works really satisfying: "They are better pictures in themselves and also show far more attention to the text than any that have yet been submitted to me" (Andrews, 2018) (Fig. 6). He goes on explaining that the publishers and he decided long ago not to have The Lord of the Rings illustrated for fantasy works from mind to mind and that illustrations present only one kind of representation. Still, he goes on to note that after viewing the work, he is beginning to change his mind and thinks that perhaps an illustrated edition might be a good idea with artwork that is more "noble" and "aweinspiring" than the ones produced before for his books. In a second letter exchanged with Ms. Fairburn, Professor Tolkien explains that he has spoken with his publisher Mr. Unwin about the possibility of an illustrated edition which Mr. Unwin seems open to considering yet such an edition has not been published (Andrews, 2018). From his views on the work of Ms. Fairburn, it can be deduced that Professor Tolkien valued fidelity to the text and more importantly, a sense of "nobility" and "awe" to come through the illustrations.
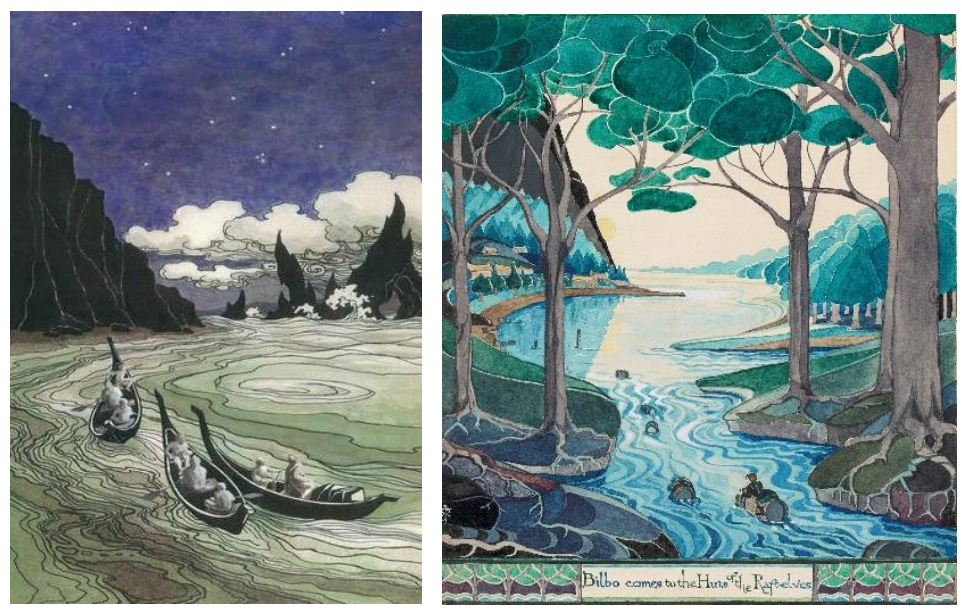

Figure 6: (Left) Fairburn, M. (1968). The Lord of the Rings. / (Right) Tolkien, J. R. R. (1937).

Bilbo Comes to the Huts of the Raftelves, from The Hobbit. George Allen \& Unwin Ltd.

One illustrator whose work has been published in a 1977 Danish edition of The Lord of the Rings 
is Ms. Ingahild Grathmer, the pseudonym of Queen Margrethe II of Denmark, who was the Crown Princess when she got in touch with Professor Tolkien (Davis, 2012). One of the queen's biographers is said to have noted that Professor Tolkien was struck by the similarities between her illustrations and his own (Fig. 7). Some point of overlap maybe summarized as art relying heavily on lines, landscape depicted with lines and shapes to make it almost look abstract and perhaps a sense of ornamentation.
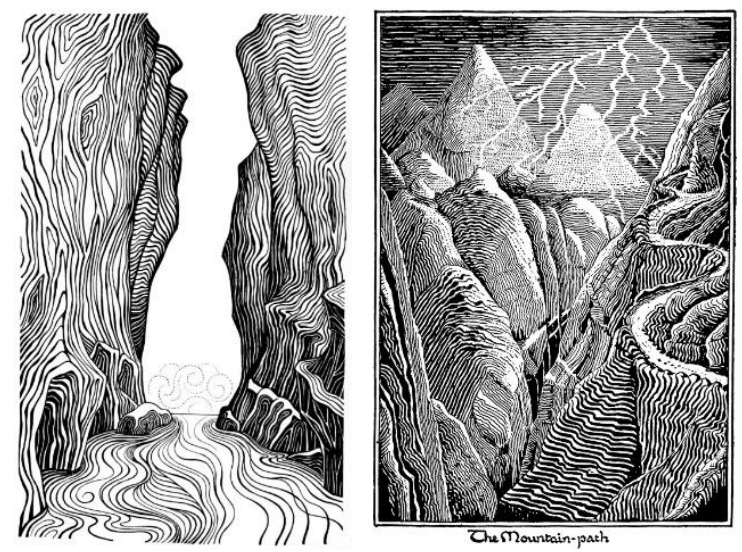

Figure 7: (Left) Grathmer, I. (1977). Inside cover art for The Two Towers, from The Lord of the Rings. The Folio Society. / (Right) Tolkien, J. R. R. (1937). The Mountain-Path, from The Hobbit. George Allen \& Unwin Ltd.

Dutch illustrator Cor Block who uses an illustration style in the vein of Medieval murals recalls a conversation he had with Professor Tolkien on "the desirability or un-desirability of illustrations to accompany a text" noting that the professor was not in favor of "coupling pictures with his texts not even his own drawings" (Block, 2011: 3). Block goes on to relay that while reading Scull and Hammond's "Tolkien Companion and Guide", he came upon a letter the author sent to his publisher about an illustration by Block that he purchased ("The Battle of the Hornburg") being both attractive and a good illustration while not fulfilling his wish for art that depicts "the noble and the heroic" (Scull, Hammond, 2017: 1184) which once again underlines the professor's insistence on "nobility" in art.

It is noted that Richard "Horus" Engels, the London born German illustrator, contacted Profe ssor Tolkien in 1946 about putting out an illustrated German edition of the Hobbit. Professor Tolkien states that he finds Mr. Engels' illustrations too "Disnified" for his taste (he had the right to veto any illustration influenced by the Disney studios for his books) (Carpenter, Tolkien, 2000: 24) 
going on to elaborate his dissatisfaction with the illustration of Bilbo with a dribbling nose and Gandalf as a "figure of vulgar fun rather than the Odinic wanderer" that he imagines (Carpenter, Tolkien, 2000: 138). While the author strays away from Engels' illustrations, he backs away from Milein Cosman's work because while the story is location based and the places in it are plainly indicated, the illustrations do not represent the locations He notes that there are incongruencies between the illustrations and the text (Carpenter, Tolkien, 2000: 151). These remarks prove that Professor Tolkien preferred nobility rather than cartoonishness and great attention to the text illustration correlation which he seems to have found in the work of the illustrator Pauline Baynes.

\section{Tolkien Book Illustrations of Pauline Baynes}

The illustrator Pauline Diana Baynes, known mainly for her collaborations with authors J. R. R. Tolkien and his friend C. S. Lewis, was born on the $9^{\text {th }}$ of September 1922 in England. In her lifetime, she contributed to more than 200 books, Lewis' Chronicles of Narnia books and Professor Tolkien's books of short stories among them (Blackwell's Rare Books, 2018). She has also painted covers, slipcases and posters for Professor Tolkien's The Hobbit and The Lord of the Rings trilogy. Her work is discernable by imaginative ornamentation, lively and confident line work that creates a sense of movement and energy and the use of bold and vibrant color.

As a baby, Ms. Baynes is taken to India for her father's work and spends some of her formative years in the cities of Agra and Mussoorie. As is the case with Rudyard Kipling, the author of The Jungle Book, Ms. Baynes is taken back from India to England at the age of 5 where she begins her education and has a rough start due to standing out with her ability to speak Hindi and fantastical imagination (Henshall, 2008). At the age of 9, the artist attends the convent school Beaufort where it is noted her favorite subject is art and by the time she graduates, she is thinking about illustration as a profession. When she is 15, Ms. Baynes studies design at what is today the University for the Creative Arts. Following in the footsteps of her sister, she later gets into the prestigious Slade School of Fine Art where she studies and is influenced by the works of artists such as Gustave Dore, Arthur Rackham, Edmund Dulac as well as the illuminations in mediaeval manuscripts (Thorpe, Zimmerman, 2012). 
One year after the beginning of World War II, Ms. Baynes and her sister join the Women's Voluntary Service where they meet Powell Perry whose family owns a company publishing picture books for children and through this connection the artist begins producing artwork for books such as a novelization of "The Magic Flute" (Sibley, 2008). Until the end of the war, the Baynes sisters create maps for the Royal Navy, a pursuit Ms. Baynes may have recalled later when illustrating maps of Middle-Earth and Narnia. During this time, a letter that the artist writes to one of her friends includes a drawing that is passed on to an employee of the magazine Country Life that result in Ms. Baynes being commissioned to illustrate books of fairy stories "Clover Magic", "The Magic Broom” and "Magic Footstool” by Victoria Stevenson (Henshall, 2008).

Pauline Baynes' connection with Professor Tolkien comes after creating her own children's book "Victoria and the Golden Bird" in 1948, when she sends comic reinterpretations of a book of illuminated psalms to the publisher of The Hobbit, Allen \& Unwin. This coincides with Professor Tolkien sending the firm a medieval comedic novella, Farmer Giles of Ham. The publisher contacts Ms. Baynes due to the author's dissatisfaction with the artwork previously submitted to request sample artwork where illustrations need not be juvenile and require "historical and topographical (Oxford and Wales) realism" (Scull, Hammond, 2017: 112-113). In late September, Professor Tolkien visits the publisher to view sample artworks of potential illustrators and chooses Pauline Baynes' on the strength of her ink and watercolor drawings in the fashion of manuscript illuminations which capture the mood of the professor's mock-medieval story (Scull, Hammond, 2017: 525). As Ms. Baynes begins sending work that displays research of period architecture and passion for recreating the costumes and fabric of daily life, the author is delighted and notes that they are "the perfect counterpart to the text" considering them a collateral theme, making the text "a commentary on the drawings" (Carpenter, Tolkien, 2000: 155). As the publication of the novella approaches, Professor Tolkien opts to directly contact Ms. Baynes, writing to her that he has a "long romance in sequel to "The Hobbit" that he hopes she will have a look at in hopes of providing illustrations (Scull, Hammond, 2017: 538). It is noted elsewhere that when the time comes for The Lord of the Rings to be published, the only illustrations the professor wants included are his own "Doors of Durin" and "the fragments of the Book of Mazarbul" which are more in the vein of artifacts or recreations of actual objects rather than illustrations. Cor Block notes that Professor Tolkien "did not want his readers to see his characters through the eyes of any individual artist, as we see Alice through the eyes of John Tenniel" (Scull, Hammond, 2017: 1185). In the 
$20^{\text {th }}$ of October 1949, Farmer Giles of Ham is published marking the first collaboration of Professor Tolkien and Ms. Baynes (Fig. 8). She returns to the book in 1999 to illustrate a map of the setting of the Little Kingdom of the story.

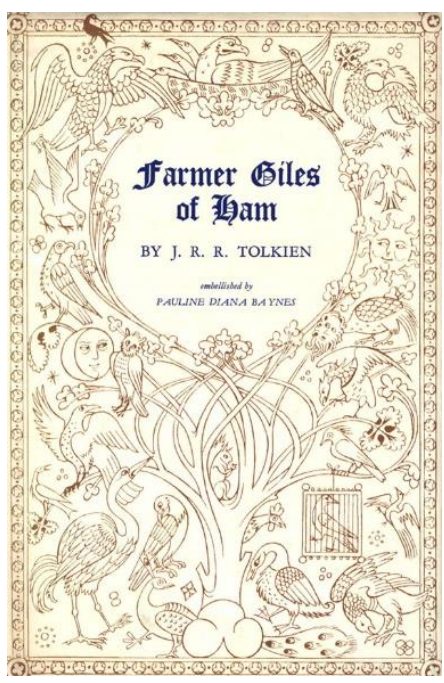

Figure 8: Baynes, P. (1949). Cover illustration and design for Farmer Giles of Ham. George

Allen \& Unwin Ltd.

Before her further collaborations with J. R. R. Tolkien, Ms. Baynes is contacted by C. S. Lewis, a close friend of Professor Tolkien's, who gets in touch about illustrating The Lion, the Witch and the Wardrobe, the first of The Chronicles of Narnia books (Scull, Hammond, 2017: 544), which sees print in 1950 with 43 of Ms. Baynes' illustrations. Later, the artist provides all the artwork for the six sequels of the book which keep her busy through most of the 1950s. After this, Ms. Baynes' second collaboration with Professor Tolkien's comes in 1961 when the author turns to the artist for the artwork for some short poems which later come to be titled "The Adventures of Tom Bombadil". Thinking that the first poem about Tom Bombadil and some other verses he has written might make a nice booklet if Ms. Baynes would illustrate them, Professor Tolkien writes that the poems sent to her are conceived as precise fantastical, nonsensical pictures "but not dreamlike!" (Scull, Hammond, 2017: 856). It seems that the professor is adamant about specificity and accuracy in the depiction of places and details of characters and though the stories may be lighthearted, he chooses not to have them relayed as being too dreamy and grounded in some kind of realism. He writes to Ms. Baynes: "I thought of you, because you seem able to produce wonderful pictures with a touch of 'fantasy', but primarily bright and clear visions of things that one might really see" (Scull, Hammond, 2017: 856). This might show that while achieving 
believability is not the author's goal, the creation of things that "one might really see" increases the feeling of desire. From the correspondence of the author and illustrator, it might be deduced that Ms. Baynes has expressed that illustration does not have a place in ambitious literary work to which the professor replies with: “... there is a case for illustration (or decoration!) applied to small things such as these verses, which are light-hearted, and (I think) dexterous in words, but not very profound in intention" (Carpenter, Tolkien, 2000: 332). Professor Tolkien describes that he has vivid narrative pictures that he has difficulty communicating and will be different from those in the minds of the readers yet is confident Ms. Baynes' illustrations will be to his liking, even enriching his own imagination (Scull, Hammond, 2017: 873). This proves to be the case when he sees the work and states "I do not think that they could have been more after my own heart", making him envious of the illustrator's skill (Scull, Hammond, 2017: 875) (Fig. 9). From these remarks, it is observable that Ms. Baynes' artwork that is built upon realism with attention to medieval period accuracy takes flights of fancy into the realm of the fantastic and thus is able to satisfy Professor Tolkien's expectations of fantasy illustration.

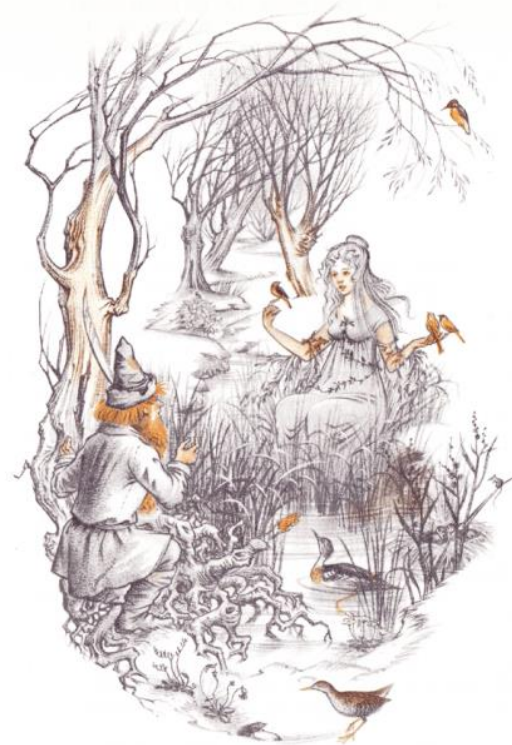

Figure 9: Baynes, P. (1962). Tom Bombadil and Goldberry, from The Adventures of Tom Bombadil. George Allen \& Unwin Ltd.

The cover of the 1961 printing of The Hobbit and the slipcase of the 1964 printing of The Lord of the Rings, which becomes one of the widely recognized artworks for Professor Tolkien's work as it is also used as the cover of a one volume edition of the book printed in 1968 and 1981, are collaborations Pauline Baynes has with the author after The Adventures of Tom Bombadil. For 
the slipcase, Professor Tolkien believes a scenic design will work best and that Ms. Baynes "has a good scenic imagination" which turns out to be exactly right for when the author is presented the artwork he is enchanted and states that Ms. Baynes has "exactly his eye for landscape" (Scull, Hammond, 2017: 907) (Fig. 10).

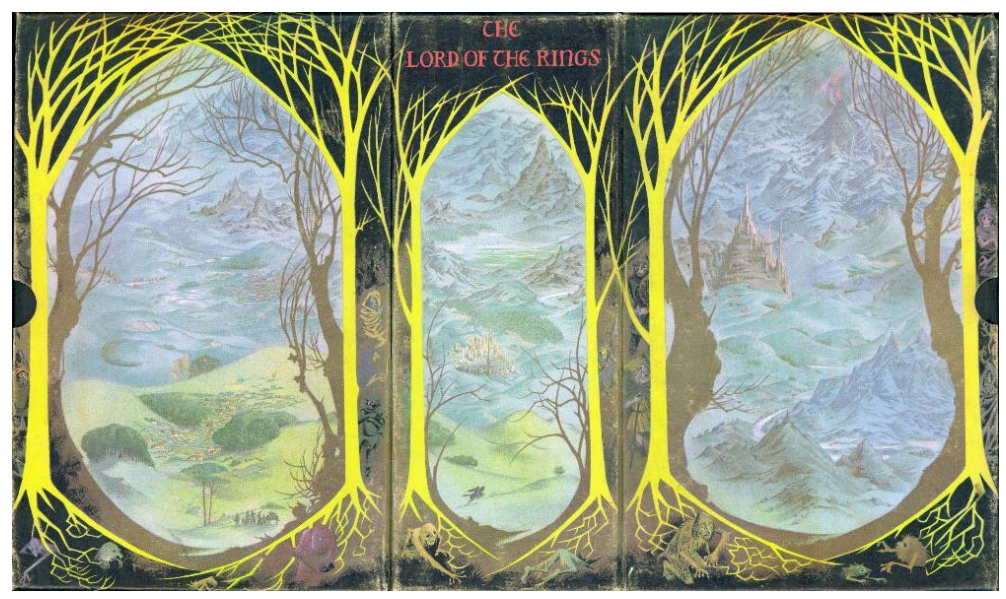

Figure 10. Baynes, P. (1964). The slipcase illustration and design for The Lord of the Rings. George Allen \& Unwin Ltd.

The artist illustrates Smith of Wootton Major in 1967, the last of the author's works to be published within his lifetime. Tolkien is delighted with her artwork, asking only that the illustrations appear in simple black and white (Fig. 11) which he found so successful with Farmer Giles of Ham. The last Tolkien art Ms. Baynes creates is also of Smith of Wootton Major for an audiobook issued in 2003 where the story is presented along with the professor's story Leaf by Niggle (Sibley, 2008). 


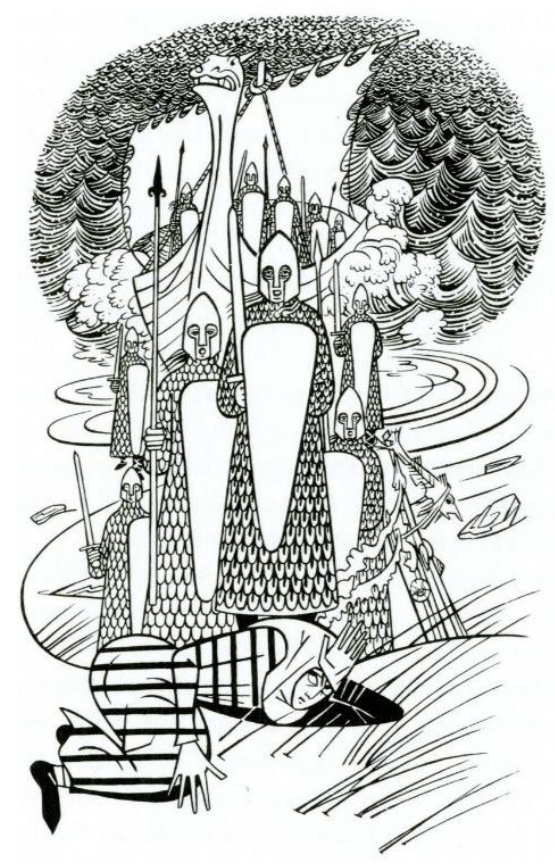

Figure 11. Baynes, P. (1967). An inside illustration from Smith of Wootton Major. George Allen \& Unwin Ltd.

In 1969, Allen \& Unwin commission Ms. Baynes to illustrate a poster-map of Middle-Earth. Ms. Baynes and her husband visit Professor Tolkien and together they work on the annotation on a copy of the Lord of the Rings map. The author expresses his only concern as being "that names should be spelt right' and is confident that Ms. Baynes will provide an attractive poster (Scull, Hammond, 2017: 1087). The poster map is published in 1970, with a header and footer displaying the main characters of the story and also vignettes of the story's locations (Fig. 12). In 1971, a companion poster-map of The Hobbit, again illustrated by Ms. Baynes is published by Allen \& Unwin. Ms. Baynes' third and final poster for the professor's work is "Bilbo's Last Song", depicting the young Hobbits watching an elven ship carrying Bilbo and Frodo along with Gandalf and Galadriel to the Undying Lands. 


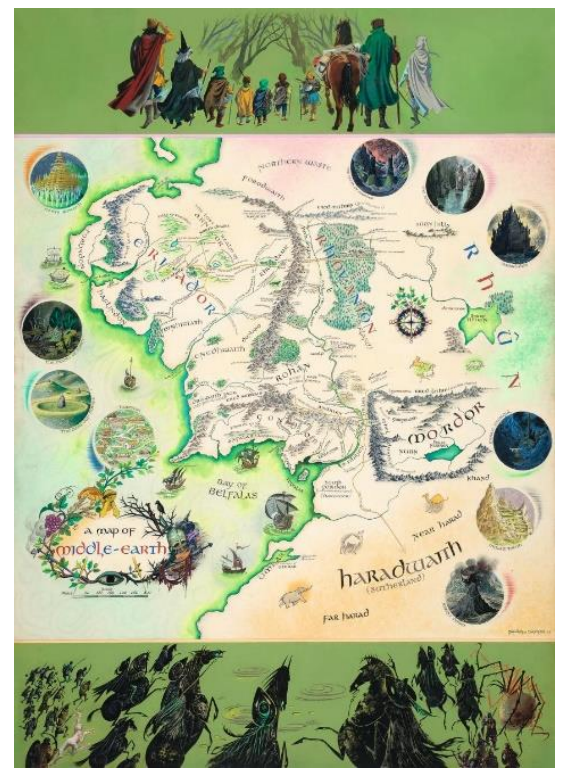

Figure 12. Baynes, P. (1970). A Map of Middle-Earth. George Allen \& Unwin Ltd.

In her lifetime, Pauline Baynes illustrates many medieval stories and her great accomplishment arrives with the 600 illustrations for A Dictionary of Chivalry that earns her the Kate Greenaway Medal. Most of the art that she has created for Professor Tolkien's along with C. S. Lewis's books has remained in print ever since they were first published, making her one of the most influential illustrators of the $20^{\text {th }}$ Century. It is reported that Ms. Baynes passed in 2008 while still working on a decorative version of The Quran along with a highly colorful rendition of Aesop's Fables (Thorpe, Zimmerman, 2012).

Pauline Baynes' work has been compared to Islamic illumination in its "extremely minute detail and perfection of finish" (Patterson, 1980: 3). It is reported that she worked "size as", meaning that the original artwork is exactly the same size as the published version as "she felt she had to know what the art would look like when it was reproduced" (Springett, 2008). While the illustrations may have indicated firm pen work, the refined articulation is created by brush and most of the colored work prepared throughout her 60 year career has employed gouache. With these tools and techniques, Ms. Baynes has been able to create images combining reverence, humor, naturalism, simplicity. Of Ms. Baynes, Patterson remarks:

- What she has, in common with Lewis and Tolkien, is the capacity to make goodness which includes both the physical and psychic world of the imagination - beautiful, attractive, and alive. (Patterson, 1980: 4) 
This notion of making imagination beautiful, attractive and alive seem perfectly in line with Professor Tolkien's purpose of creating desire in the reader and may prove the underlying reasons he was drawn to Ms. Baynes' work in the first place.

From the documents on the correspondences of J. R. R. Tolkien, it may be concluded that he had found a perfect counterpart for his texts with the illustrations of Pauline Baynes, for they displayed historical and topographical realism, attention to detail of medieval architecture and costume, a good scenic imagination, strong ink and watercolor drawings that were fantastical yet provided clear visions of things that one might really see. All of these qualities seem to also apply to a wellknown, contemporary illustrator; namely: John Howe.

\section{Tolkien Book Illustrations of John Howe}

Illustrator and conceptual designer John Howe, best-known for fantasy illustrations for J. R. R. Tolkien's Middle-Earth stories, notes that he was drawing from pre-school age, sometimes becoming frustrated that he could not draw something the way he exactly wanted to. During his high school years, his biggest influence is the fantasy, science fiction book and comic book illustrator Frank Frazetta whose works he copies copiously. He also collects fantasy comic books illustrated by Barry Windsor-Smith and Bernie Wrightson. After he reads The Lord of the Rings, he is captivated by the promotional calendars published by Hildebrandt Company which show to him that the book can be illustrated and he tries to re-illustrate the scenes depicted in the calendar. He attends college at Ecoles des Arts Decoratifs where he feels he is out of step with the program yet acknowledges that whatever "clarity of thought" he possesses is due in large part to his professor of illustration (Howe, 2001: 7). This period in Europe is a time of soaking in all forms of art and architecture for Mr. Howe, where things are novel and ancient and may be thought of as having influenced his artwork in an important way (Fig. 13). His earlier work is comprised of political cartoons, magazine illustrations, comics, animated films and advertising that do not sit well with him and he regards this time as having been a nightmare, where the works have nothing of his personality or style in them. As with Pauline Baynes before her, Mr. Howe illustrates postermaps of The Lord of the Rings and The Hobbit along with The Silmarillion. After working for years illustrating Professor Tolkien's Middle-Earth, Mr. Howe, alongside Alan Lee, another 
important Tolkien illustrator, serves as chief conceptual designer for The Lord of the Rings and The Hobbit movie trilogies directed by Peter Jackson. The illustrator's work covers a wide variety of fantasy stories including mythological material such as Beowulf and books by C. S. Lewis, Robin Hobb and George R. R. Martin. He has expertise in medieval armour and is a member of the living-history group the Company of Saynt George that portrays an artillery compnay in the 15th Century, doing events where medieval civil and military life are displayed (Howe, 2001: 9).

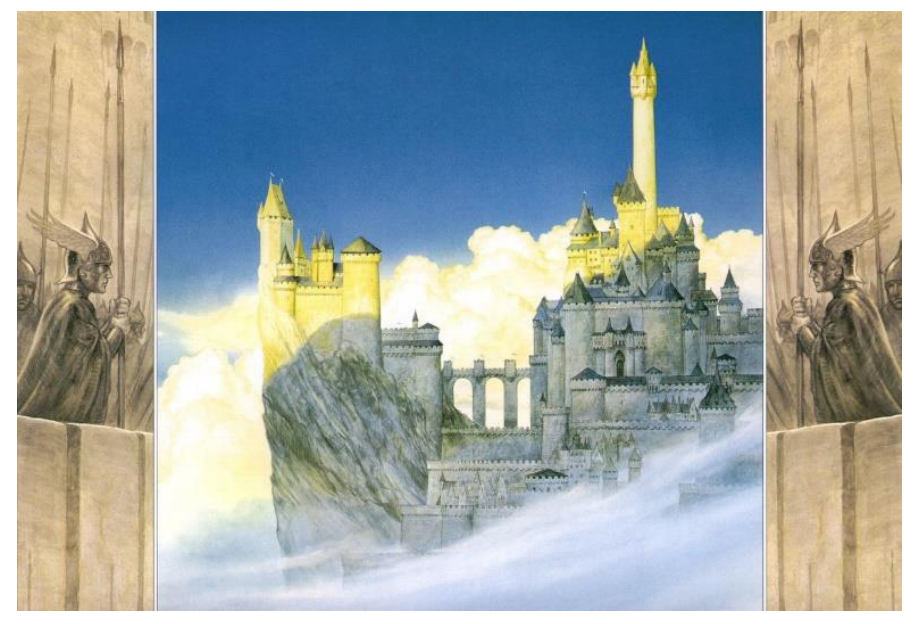

Figure 13: Howe, J. (1989). Minas Tirith. (63.5 x $47.3 \mathrm{~cm})$.

John Howe's work feels at once familiar like something one remembers from a dream or a previous life and also something one longs for as if a home one has had to leave and cannot get back to. This sense of familiarity may be due to the illustrations being grounded in history and his extensive research into architecture, armour and artifacts while extending the frame to include fantasy to seep in (Fig. 14). To him, illustration is "a form of communion" with a subject that may either be in front of the illustrator or in their imagination where the skill of the illustrator matches their desire to express and share their world and thus is very personal (Howe, 2007: 11). It is with this personal conenction that an artist is able to create "enchantment" that "should open a window on another world, rather than clothing our own in fantasy trappings" (Howe, 2007: 19):

- For me, fantasy imagery involves "glamour" (in its archaic sense of enchantment), and implies a suspension of rationality. It refers to worlds and creatures derived from myth or invented by creative minds in the same vein. Its fully realized worlds have elements that we cannot physically experience - they are generally pre-industrial, slowly blending into science fiction as they move forward in time, trading suspension of disbelief for belief in 
the promises of science. Teleportation, for example, is magical in a medieval setting if done by a mage, but it's sci-fi on the Starship Enterprise (Howe, 2007: 22).

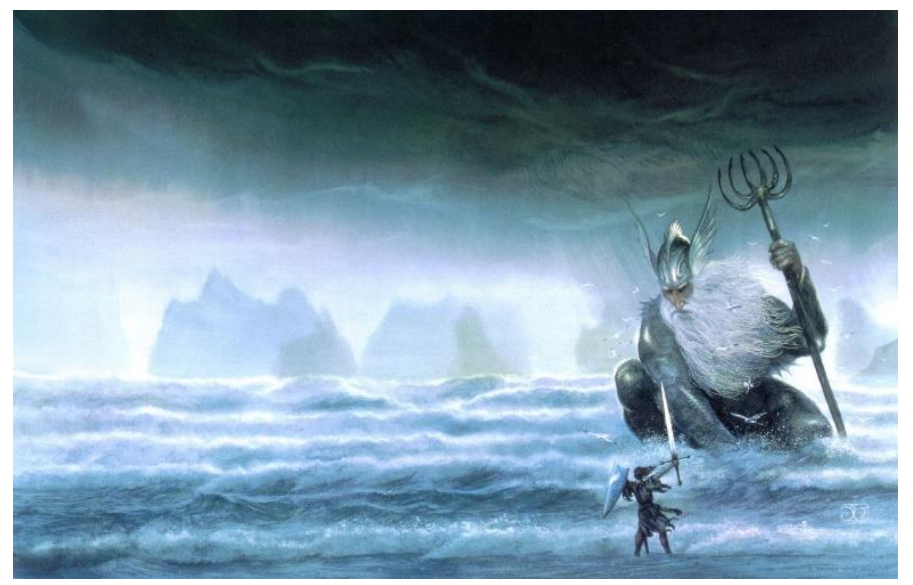

Figure 14: Howe, J. (1991). Ulmo, Lord of the Waters. (63.5 x $41.5 \mathrm{~cm})$.

From his views on illustration and specifically illustrating the works of J. R. R. Tolkien, it is observable that with his works, John Howe is always thinking of ideal or archetypal images, icons that when a tree is illustrated, it would "contain and evoke all trees" that encompasses all the trees that each viewer carries around with themselves in their imaginations (Davoust, 2003: 194) because he believes that Professor Tolkien's descriptions, where every word is worth a thousand pictures, are outside our experience, archetypal and demand to be illustrated as such. The landscapes are symbolic and are so much a part of our cultural heritage that they are personal and also shared by millions. Mr. Howe states that paintings and films may be made of Middle-Earth, for it is an intensely visual world with images in the words having exceptional clairty, yet it cannot be illustrated and none of the images can be definitive. He describes the visual representations as "sketches, imperfectly glimpsed through shifting cloud and mist" (Howe, August 2003). Here, he notes that the word "illustration", in its meaning of "providing light, the act of making lustrous or clear" is appropriate in that, what the illustrator of Middle-Earth tries to do is shine a little light here and there, not obliged to show too much and allow "the intuitive to take precendence over the encyclopaedic" (Howe, August 2003). This brings about the illustrator's dislike for the use of unnecessary detail in fantasy illustration in order to make the Secondary Worlds seem realistic. Mr. Howe is of the mind that illustrations packed with too much detail present walls rather than windows that look out into a Secondary World. While a detailed technique may be impressive, “over-elaboration", as Professor Tolkien put it, may run the risk of containing a personal 
connection on the part of the illustrator, reducing the image to a hallow surface. J. R. R. Tolkien is said to include details to further the narrative of his stories and writes to an audience that he counts on to have knowledge of past cultures in order to understand what he is describing. Thus, Mr. Howe believes that the illustrations should be in a similar vein, focusing on telling or hinting at a story and unless contradicting the text, forming a personal connection with the subject being illustrated (Davoust, 2003: 194). This way, it may be possible to get a glimpse through the mist, of Middle-Earth which he believes is a world beyond images (Fig. 15).

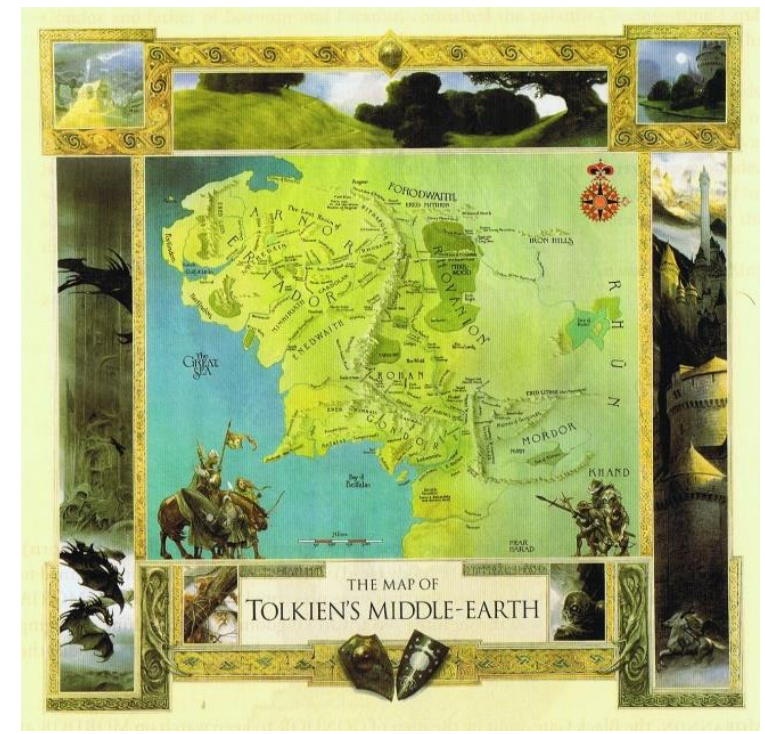

Figure 15: Howe, J. (1994). The Map of Tolkien’s Middle-Earth. Harper Prism.

John Howe's views on fantasy illustration having the quality of enchantment and presenting windows that provide brief glimpses into a Secondary World are supported by his writing where he discusses an introduction to an exhibition of children's drawings, penned by the illustrator Edmund Dulac who was discussed as a possible inspiration on J. R. R. Tolkien's own artworks. According to Dulac, as humans attempted to solve problems when faced with reality, Science was developed and when they stretched their activities in order to organize the forces behind consciousness, Art was born, which was at the beginning Magic that established intimate connections to the world (Howe, August 2015). Artists can conjure up at will, tangible worlds of unrealities through the use of colors, lines, sounds and other properties aimed at the senses. Mr. Howe notes that with this, Mr. Dulac points out the reason that drives the artist and specifically the illustrator; the possibility of touching with the mind "the indicible", "of conferring a form of reality to something not real - a tangible world of unrealities" (Howe, August 2015). It is also 
stated in the introduction that, children have an extraordinary degree of imagination due to their subconscious organization not being impaired by growing conscious habits and that through Art, people may yet become children again; their consciousness pulled back into a world full of wonders. This “wonder", similar to Professor Tolkien's concept of "desire”, created in the hearts of the viewers of illustration seems to be Mr. Howe's main goal to be achieved, which he calls "the Grail" (Davoust, 2003: 194).

\section{Conclusion}

In this article, J. R. R. Tolkien's ideas on fantasy and fantasy illustration, his influences in the illustrations he has created, his own illustrations and some illustrators of his work, his preference and close collaboration with the illustrator Pauline Baynes and the approach to illustration the well-known Tolkien illustrator John Howe takes have been discussed. There are many points of overlap between the understanding and approaches to illustration between Professor Tolkien, Ms. Baynes and Mr. Howe. As was discussed, Professor Tolkien deems fantastical art successful once it is able to create desire in the hearts of people through the components of fantasy, recovery, escape and consolation yet is sceptical of visual representation due to the fixed point of view it presents unlike literature which is both universal and particular to each person. While this is his thinking, for illustrations, he searches for awe inspiring visuals created through fine drawing, delicate pattern, subtle mixing of colours, fantastical complication of shapes and reqires them to exude nobility, heroism and a touch of fantasy that is rooted in research into pre-industrial periods, mainly the medieval period that allow for the fantastical Secondary World to present clear visions of things that people might really come face to face with in the Primary World. In this, Pauline Baynes succeeds due to her knowledge and skill in imbuing her work with the feeling of medieval illuminated manuscripts that still retain her own personal touch of humor, reverence, naturalism and simplicity thus making the world presented through the illustrations beautiful, attractive and alive. John Howe, aware of the archetypal quality of Professor Tolkien's texts in that the words present an intensely visual world with exceptional clarity that works from the mind of the author to the mind of the reader, tries to commune with the subject in order to shine a brief light through the illustration to provide a brief glimpse at the Secondary World of the fantasy. For this to be 
achieved, as with the works of Professor Tolkien and Ms. Baynes, Mr. Howe aims to suspend rationality to create a tangible world for people to view the incredible.

\section{References}

Andrews, S. (2018). A Remarkable Pair of Letters from Tolkien to Mary Fairburn, an Artist Who Sent Him Several Scenes from "Lord of the Rings", Sold at an Auction. The Vintage News. https://www.thevintagenews.com/2018/05/10/tolkien-letters/

Blackwell's Rare Books. (2018). Pauline Baynes: Illustrator to Lewis and Tolkien. Oxford: Blackwell's Rare Books.

Block, C. (2011). A Tolkien Tapestry: Pictures to Accompany the Lord of the Rings. Edited by Pieter Collier. New York: HarperCollins Publishers.

Bradley, W. (1896). William Morris, Artist, Poet, Craftsman. Bradley, His Book, Vol. 2, No. 1, pp. 7-11. Springfield: Wayside Press. http://www.jstor.org/stable/20443197

Carpenter, H., Tolkien, C. (2000). The Letters of J. R. R. Tolkien. Boston: Mariner Books.

Clutton-Brock, A. (2007). William Morris. New York: Parkstone International.

Davis, L. (2012). The Middle Earth Illustrators J. R. R. Tolkien Loved - and the Ones He Abhorred. Gizmodo. https://gizmodo.com/the-middle-earth-illustrators-j-r-r-tolkien-loved-and-5968792

Davoust, L. (2003). Rencontre avec John Howe a l'Occasion de la Semaine Tolkien. Asphodale, No. 4. Paris: Imaginaires Sans Frontieres.

Hammond, W. G., Scull, C. (1995). J. R. R. Tolkien: Artist \& Illustrator. New York: Houghton Mifflin Company.

Henshall, D. (2008). Pauline Baynes: Witty and Inventive Children's Book Illustrator Famed for her Narnia Drawings. The Guardian. https://www.theguardian.com/books/2008/aug/06/booksforchildrenandteenagers

Howe, J. (2001). Myth and Magic: The Art of John Howe. New York: HarperCollins Publishers. Howe, J. (August 2003). Meditations and Mediations. John Howe Chronicles. https://www.john- 
howe.com/blog/2003/08/03/meditations-and-mediations/

Howe, J. (2007). John Howe: Fantasy Art Workshop. David \& Charles Limited: Cincinnati.

Howe, J. (August 2015). Nothing Childish About Children's Drawings. John Howe Chronicles. https://www.john-howe.com/blog/2015/08/14/nothing-childish-about-childrens-drawings/ - _ftn1

Izzard, J. (1968). In Their Own Words: British Novelists, John Ronald Reuel Tolkien. https://www.youtube.com/watch?v=mgU2wLCuGv0

Johnstone, J. (2019). Pauline Diana Baynes: An Artist's Inspiration. The Tolkien Society. https://www.youtube.com/watch?v=c2qITmhh1RU

Leroy, M. (2016). The Golden Age(s) of British Illustration. Studies in Literature and Culture, Vol. 14, pp. 165-180. Lublin: University of Lublin Press.

MacLeod, J. J., Smol, A. (2017). Visualizing the Word: Tolkien as Artist and Writer. Tolkien Studies, Vol. 14, pp. 115-131. West Virginia: West Virginia University Press.

Menges, J. A. (2008). Rackham's Fairies, Elves and Goblins. New York: Dover Publications, Inc. Nielsen, K. (2006). Nielsen's Fairy Tale Illustrations in Full Color. Mineola: Dover Publications, Inc.

Patterson, N. L. (1980). An Appreciation of Pauline Baynes. Mythlore: A Journal of J. R. R. Tolkien, C. S. Lewis, Charles Williams, and Mythopoeic Literature, Vol. 7: No. 3, Article 1. Mythopoeic Society: Los Angeles.

Peitcheva, M. (2016). Arthur Rackham: Drawings - Colour Plates. California: CreateSpace Independent Publishing Platform.

Phillips, S. C. (1919). The Stationery World and Allied Painting Trades. S.C. Phillips \& Company, Vol. 56, pp. 6, 18, 116. https://books.google.com.tr/books?id=wBRbAAAAYAAJ\&pg=RA1PA6\&redir_esc $=\mathrm{y}$

Plato. (2004). The Republic: With an Introduction and Notes by Elizabeth Watson Scharffenberger. New York: Barnes \& Noble Classics.

Pook Press. (2018). Jennie Harbour: A Biography of the Illustrator. Pook Press. https://www.pookpress.co.uk/project/jennie-harbour-biography/ 
Russell, N. (2015). A Hollywood Master Remembered. Verso: The Blog of the Huntington Library, Art Museum, and Botanical Gardens. https://www.huntington.org/verso/2015/05/hollywood-master-remembered

Scull, C., Hammond, W. G. (2017). The J. R. R. Tolkien Companion and Guide, Vol. 1: Chronology. London: Harper Collins Publishers.

Sibley, B. (2008). Pauline Baynes: The Queen of Narnia and Middle-Earth. Brian Sibley: his blog. http://briansibleysblog.blogspot.com/2008/08/pauline-baynes-queen-of-narnia-and.html

Sizeranne, R. d. 1. (2008) The Pre-Raphaelites. New York: Parkstone International.

Springett, M. (2008). Pauline Baynes - The Queen of Narnia. The Art and Music of Martin Springett. http://www.martinspringett.com/paulinebaynes.html

Thorpe, P., Zimmerman, R. (2012). About Pauline Baynes. Pauline Baynes 1922 - 2008. https://www.paulinebaynes.com/?what=about

Tolkien, J. R. R. (2008). Tales From the Perilous Realm. Boston: Mariner Books. 